\title{
REVIEW ON PHORBOL ESTER DEGRADATION OF JATROPHA SEED CAKE FOR ITS USE AS ANIMAL FEED
}

\author{
SHILPI AHLUWALIA ${ }^{1 *}$, RAJKUMAR BIDLAN ${ }^{1}$, JAI GOPAL SHARMA ${ }^{1}$, PUSHPENDRA SINGH ${ }^{2}$ \\ ${ }^{1}$ Department of Biotechnology, Delhi Technological University, Delhi 110042, India, ${ }^{2}$ Department of Mechanical Engineering, Delhi \\ Technological University, Delhi 110042, India \\ Email: shilpi.ahluwalia@gmail.com
}

Received: 26 Sep 2016 Revised and Accepted: 27 0ct 2016

\begin{abstract}
Jatropha curcas is an oil-seed plant with good adaptability to grow in unfavourable conditions like infertile soil with scanty rainfall. It had been exploited for the extraction of oil for bio-diesel. The compressed seed cake, after the oil extraction, is a rich source of protein with certain toxic and anti-nutritional factors. The major toxins in the seed cake are phorbol esters and trypsin inhibitors that lead to various health problems if ingested. Even though the application of the various extracts carries a lot of beneficial advantages, yet the toxicity in oil and the compressed cake does not allow the by-products and the oil to be used elsewhere. Various physicochemical and biological methods have been described for the detoxification of Jatropha seed cake and oil of which the chemical extraction with methanol and ethanol have shown promising results in reducing the toxin contents by $97-100 \%$ while UV-irradiation reduced the phorbol esters completely. Submerged fermentation by Bacillus sp. achieved complete detoxification of phorbol esters within a week. A new strain was found to degrade the phorbol esters to phorbol, myristic acid and acetic acid within $12 \mathrm{~h}$ of incubation in submerged fermentation process. The detoxified products, in future, can be used as animal feed and food supplement to help utilize the by-products as a healthy diet.
\end{abstract}

Keywords: Jatropha curcas, Phorbol esters, Biodegradation, Submerged fermentation, Detoxification

(c) 2017 The Authors. Published by Innovare Academic Sciences Pvt Ltd. This is an open access article under the CC BY license (http://creativecommons.org/licenses/by/4. 0/) DOI: http://dx.doi.org/10.22159/ijpps.2017v9i1.15380

\section{INTRODUCTION}

Jatropha is an oilseed plant belonging to Euphorbiaceae family which has gained remarkable interest as a raw material for biodiesel industries. It is one of the crops being highly studied for the production of biodiesel for the reason that it can be grown in unfavourable climatic regions like unfertile soils and little rainfall. The Jatropha seed contains approximately 30-35\% oil that can be converted into high-quality biodiesel upon trans esterification and can be used as a substitute for diesel fuel [1]. The seed cake remaining after oil extraction is an excellent source of plant nutrients which is rich in lignocellulosic compounds, water, minerals and proteins but at the same time it contains many toxic and antinutritional compounds such as phorbol esters, phytic acid, trypsin inhibitors, phenolic compounds, lectins (curcin), and saponins in high amounts. Phorbol esters have been identified as one of the main compound responsible for the toxicity that limits the utilisation of Jatropha seed cake for animal nutrition. Different methods have been employed for the detoxification of the Jatropha seed cake that would allow the use of detoxified meal as a protein-rich dietary supplement in the food or feed diets. Many researchers have used physical and chemical treatments to detoxify Jatropha seed [2-4]. In this paper, we review the properties of Jatropha toxins and various treatments adopted to detoxify them.

\section{History of Jatropha}

The Jatropha curcas plant is a native of Mexico and states of Central America and was later grown by Portuguese traders as a hedge plant and got spread to Asia and Africa [5, 6]. Jatropha curcas belongs to Division-Magnoliophyta, Class-Mangnoliopsida, Order-Malpighiales, Family-Euphorbiaceae, Subfamily-Crotonoideae, Tribe-Jatropheae, Genus-Jatropha, and Species-Curcas [7]. The genus Jatropha has approximately 175 known species. The genus name Jatropha is derived from the Greek word jatros (doctor), trophe (food), which suggests its medicinal uses. Hence the plant has been traditionally used for medicinal purposes [4]. The most common vernacular names of Jatropha curcas in India are Ratanjyot (Hindi), Safedarand, Physic nut (English), Purging nut (English), Katamanak (Malayalam), Kattamanakku (Tamil), Pepalam (Telugu), Jepal (Gujrati),
Kananaranda (Sanskrit), Chandrajyot etc [8]. Jatropha is a large shrub or small tree usually 3-5 $\mathrm{m}$ in height with a smooth grey bark (fig. 1), which when cut exudes watery and sticky latex. It grows on well-drained soils with good aeration [9] and is well adapted to soils with low nutrient content. They are widely distributed in the tropical and the subtropical Himalayas, the mountains of Western and Eastern Ghats and plains of South India [10]. In India, 18 species are found distributed in various parts of the country which are Jatropha curcas, Jatropha gossypifolia, Jatropha glandulifera, Jatropha heynei, Jatropha integerrima, Jatropha maheshwarii, Jatropha multifida, Jatropha mulendnifera, Jatropha villosa, Jatropha nana, Jatropha podagrica, Jatropha hastate, Jatropha tanjovurensis, Jatropha hastate, Jatropha macrofayala, Jatropha acrocurcas, Jatropha diyoka and Jatropha sinera. Out of these, Jatropha curcas gained importance because of its additional features like adaptability to various habitats, larger fruits and seeds, high oil yield, soil conservation capabilities, etc.

\section{Composition of Jatropha}

Jatropha curcas is an economic tree that cultivates well in the subtropical and tropical climate, and therefore plays an essential role in controlling soil erosion and land restoration [11-13]. It is considered to be a good source of proteins and lipids indicating good nutritional value.

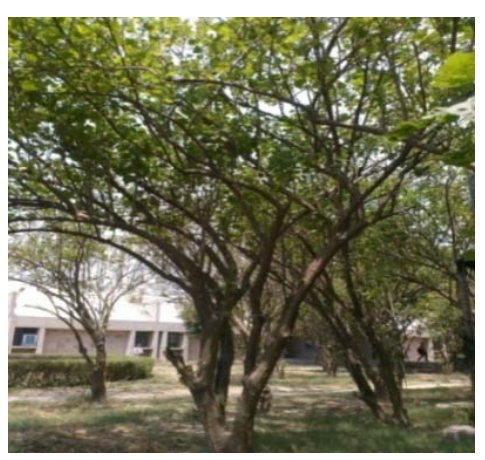

Fig. 1: Jatropha tree 
The study of Jatropha curcas seeds showed that it contains; moisture $6.62 \%$; protein $18.2 \%$; fat $38.0 \%$; carbohydrates $17.30 \%$; fibre $15.50 \%$; and ash $4.5 \%$ [14]. The oil from the seed of Jatropha curcas can serve as a good source of oil for biodiesel production and for this purpose several tonnes of seed are utilised which results in the production of de-oiled seedcake. Jatropha proteins can be obtained from the press cake which contains around $25 \% \mathrm{w} / \mathrm{w}$ proteins. The defatted pressed Jatropha seed cake has high protein content, and the essential amino acid contents are higher than the FAO amino acid reference except for lysine [15]. In terms of functional properties and extraction conditions, Jatropha protein may be considered as good as to other well-known oilseed proteins such as rapeseed, canola, or sunflower proteins. Proteins from plants are less expensive than animal proteins so they can be effectively used for fortification and formulation of food products with desirable functional properties. Jatropha proteins could be produced as the existing industrial proteins e. g. soy proteins, casein, or wheat gluten. However, toxic compounds like curcin and phorbol esters restrict the use of Jatropha proteins for food applications. Jatropha proteins after detoxification may serve as potential components for animal feed, while without detoxification their use will be limited to technical applications only. At the industrial level, for extracting proteins from Jatropha press cake with higher yields and protein recovery, a more efficient method is a prerequisite which should be able to extract proteins with good functional properties e. g. water absorption, viscosity, solubility, foaming properties, flavour binding and emulsifying properties which are essential for food/technical applications. As large volumes of biodiesel are generated, so will be the seed cake, which could support livestock production.

\section{Benefits of Jatropha}

Bioactive compounds from natural sources contain substances including phytochemicals and antimicrobials which are known to have the enormous therapeutic potential [16-18]. The increased resistivity of certain pathogens to antibiotics could be because of non-selective use of synthetic antimicrobial drugs which is a major cause of concern to the global population [19]. This, in turn, demands for an urgent need of developing the new generation antibiotics and antimicrobial agents. Many parts of this Jatropha plant are used for the curing human and veterinary diseases for eg. The white latex works as a disinfectant in mouth infections in children and as a hemostatic in cuts and bruises [20]. Also, the latex of Jatropha has anti-cancerous properties [21, 22] and can be used externally for skin diseases [23], piles and sores among the domestic livestock [24]. The leaves of Jatropha plant (fig. 2) have certain compounds which make them effective against malaria [25], rheumatic and muscular pains $[23,26]$. The roots of the plant are known to contain an antidote for snake venom [24, 27] and are also used for treating eczema, scabies, ringworm and gonorrhea [28]. Antibiotic activity of Jatropha has also been reported against certain microorganisms like Staphylococcus aureus [24, 29-35], Escherichia coli [24, 30-34]. Enterobacter aerogenes [36], Streptococcus pyogenes [33, 34, 37], Candida albicans [31, 33, 37] Salmonella typhimurium, Shigella dysenteriae, Psuedomonas aerugunosa $[31,35,38-40], P$. flourescenses, Klebsiella pneumonia and K. ozaenae [38], Aspergillus flavus, Neisseria gonorrhea [31], Erwinia carotovora, Xanthomonas sp. [40], Aspergillus niger, Penicillum fellutanum [33]. In addition to this, the seeds of Jatropha curcas comprise of about 20 to $39 \%$ oil which makes them as an important source for bio-fuel production. Also, the oil from its seeds has been found to be useful in cosmetic industry, for the production of candles, soaps and also for medicinal purposes [14, 41].

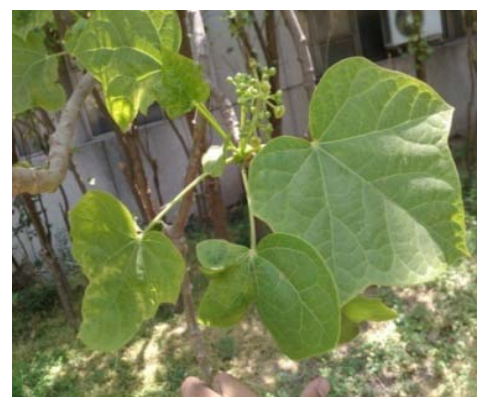

Fig. 2: Leaves and flower buds of Jatropha

\section{Toxicity in Jatropha}

The seeds and oil of Jatropha curcas have found to be toxic because of the presence of some active components like phorbol esters, phytates, lectins, saponins and trypsin inhibitors. However, the Jatropha curcas seed cake may serve as very nutritious protein supplement in animal feed, but the presence of toxins significantly restricts its use as feed. It was found to be toxic to mice, rats, sheep, calves, goats, human and chickens [3, 42-44]. The high levels of phorbol esters in the seed cake had been identified as the main agent responsible for toxicity.

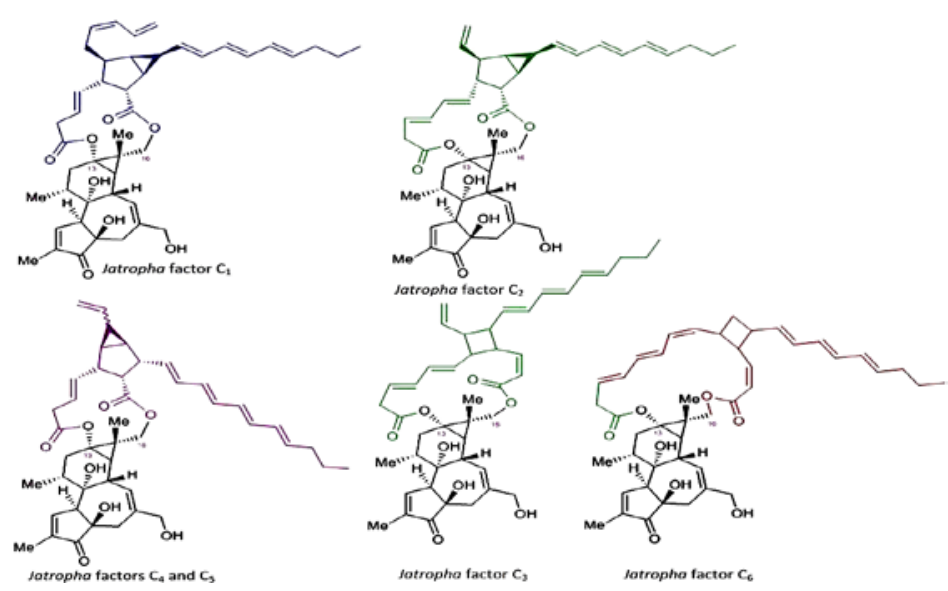

Fig. 3: Structure of phorbol esters in Jatropha curcas oil [48]

\section{Phorbol esters in Jatropha}

Phorbol esters are tetracyclic diterpenes with a tigliane skeletal structure $[45,46]$ and are highly toxic, cathartic and skin irritant. A number of plants have been reported to contain the toxic phorbols like Sapium indicum, Sapium japonicum, Euphorbia frankiana,
Jatropha curcas [47]. Haas et al. [48] characterised six phorbol esters (Jatropha factors C1-C6) from Jatropha curcas seed oil where all complexes have the same diterpene moiety, namely, 12-deoxy-16hydroxyphorbol (fig. 3). Phorbol esters are widely distributed in different parts of the Jatropha plant, but they are mainly concentrated in the seed kernel [49] and during extraction of oil 
from Jatropha seeds, being lipophilic in nature $70-75 \%$ of phorbol esters go with the oil, and $25-30 \%$ remain in the seed meal [50]. Jatropha curcas seeds are toxic to humans and animals due to the toxicity of phorbol esters. In humans, phorbol esters intoxication may lead to mouth pain, vomiting, muscle shock, high pulse or even death [51]. Erythema, oedema, necrosis, diarrhea, loss of weight, reduced water intake are some of the toxicity symptoms found in rodents, rabbits and goats when they were fed with phorbol ester containing feed. Becker and Makkar [52] carried out the toxicological study of phorbol esters in fish and observed lower metabolic rate, rejection of feed and increase in fecal mucus production as adverse effects of phorbol esters.

\section{Detoxification methods}

A lot of research has been done on the extraction of oil from Jatropha seeds. A conventional method like solvent extraction is the most extensively used technique for the extraction of oil as it results in higher oil yields along with large amount of press cake which is rich in proteins, fibre, carbohydrates and some minor components; but for its utilisation as feed, the press cake should be detoxified. Several methods have been tried for detoxifying defatted cake and kernel meal (table 1) that include physical, chemical and biological methods.

\section{Physical and chemical treatments}

The physical methods for the detoxification of Jatropha involve the heat treatment that employs the use of moist heat. Research has been done using moist heat alone for the reduction in phorbol esters content with not much breakthrough [53,54]. Moist heat along with other treatments resulted in a partial decrease in phorbol ester contents [55]. The combination of physical and chemical treatments has been demonstrated with better efficiency of detoxification [55-57].

The polar nature of phorbol esters has made the use of organic solvents such as ethanol or methanol for detoxification of Jatropha cake $[58,59]$. Treatment of Jatropha seed cake with methanol as organic solvent gave better results but the process is time- consuming as it requires a number of extractions and also the toxicity of methanol makes the process non-ecofriendly. In a study done by Rakshit and Makkar et al. [57], 99\% reduction in phorbol esters content in oil was achieved using eight litres of methanol for one kg of oil, with a total extraction time of $60 \mathrm{~min}$. Pighinelli et al. [60] reported that methanol treatment of Jatropha seed cake resulted in $100 \%$ reduction of phorbol esters as compared to the treatment with ethanol and sodium bicarbonate which resulted in 64\%decrease. Vittaya and Rayakorn [61] have observed in their study that treatment of Jatropha meal with 90\% methanol and $85 \%$ ethanol has resulted in a complete reduction in the phorbol esters. The high extraction yields of phorbol esters according to Severa et $a l$. [62] are due to hydrogen bonding interactions between methanol and hydroxyl groups of phorbol esters. The nontoxic nature of ethanol as compared to methanol has an added advantage if the detoxified meal has to be used as animal feed. Although using a combination of solvent systems is effective in reducing the phorbol ester contents but they are less suitable for large-scale use as this could complicate the extraction process and make the solvent recovery difficult. Also, the various stages involved in the processing of the biomass up to the detoxification levels increases the expenditure and make the process highly expensive. These processes may also involve the use of a combination of some chemicals that result in the presence of other undesirable residues. Combinations of treatments are used by different researchers [42, $55,63,64]$ for the removal of phorbol esters from Jatropha (table 1).

Some of the other methods of detoxification include hydrothermal processing techniques [15], ionising radiation, supercritical fluid extraction (SCFE) [65] etc. Detoxification by SCFE using $\mathrm{CO}_{2}$ would allow the use of aqueous/organic solvent extracts from Jatropha seed as an effective insecticidal and antimicrobial agent [65]. Diwani et al. [66] reported that the ozone treatment can be the best and less expensive method for removing toxic phorbol esters from Jatropha seed cake compared to other methods as the treatment removes $75.26 \%$ phorbol esters and consumes less time and chemicals.

Table 1: Physico-chemical treatments for the removal of toxins in Jatropha press cake

\begin{tabular}{|c|c|c|c|}
\hline $\begin{array}{l}\text { S. } \\
\text { No. }\end{array}$ & Process/treatment & $\begin{array}{l}\text { Effects on phorbol esters and other anti- } \\
\text { nutritional factors }\end{array}$ & Reference \\
\hline & Physico-chemical treatments & & \\
\hline 1. & Methanol/ethanol (50/50 during 8h) & Phorbol esters reduced by $97.30 \%$ in cake & [63] \\
\hline 2 & $\mathrm{NaHCO}_{3}$ or $\mathrm{NaOH}(3 \%)$ & Phorbol esters reduced by $55 \%$ in meal & [71] \\
\hline 3 & $90 \%$ methanol and $85 \%$ ethanol & Phorbol esters reduced $100 \%$ & [61] \\
\hline 4 & $\begin{array}{l}\text { Plasma generated by helium gas at high voltage and input power of } \\
\text { about } 50 \text { Win water and methanol }\end{array}$ & $\begin{array}{l}\text { Complete degradation of Phorbol esters in } \\
\text { methanol was achieved. }\end{array}$ & [72] \\
\hline 5 & Heat treatment+bentonite+zinc oxide $+\mathrm{NaHCO}_{3}(4 \%)$ & Phorbol ester content reduced to $0.05-0.04 \mathrm{mg} / \mathrm{g}$ & [57] \\
\hline 6 & Methanol & Phorbol ester reduced by $100 \%$ & [60] \\
\hline 7 & Ethanol (unknown dose) followed by $\mathrm{NaHCO}_{3}$ treatment & Phorbol esters reduced by $97.9 \%$ & [42] \\
\hline 8 & $\begin{array}{l}\mathrm{NaHCO}_{3} 0.075 \%+\text { ozone treatment for }(2,3,6,9 \text { and } 12) \text { minutes at dose } \\
50 \mathrm{mg} / \mathrm{l} \text { and } 300 \mathrm{~m} \mathrm{~A} \text {. }\end{array}$ & Phorbol esters reduced $75.26 \%$ & [66] \\
\hline 9 & Alkaline methanol+heat treatment & $\begin{array}{l}\text { Phorbol ester reduction and trypsin inhibitor } \\
\text { inactivation }\end{array}$ & {$[56]$} \\
\hline 10 & $\begin{array}{l}\text { Solid-liquid extraction with a sequential combination of hexane and } \\
\text { methanol }\end{array}$ & Phorbol esters reduced by $99.6 \%$ & {$[64]$} \\
\hline 11 & $\mathrm{CaOH}(2 \%)$ & Phorbol esters reduced by $90 \%$ in meal & [73] \\
\hline 12 & $\begin{array}{l}\text { Ethanol }(95 \%) \text { at } 35^{\circ} \mathrm{C}+\text { heating with pressurised steam at } 90^{\circ} \mathrm{C} \text { for } 30 \\
\text { min+sun-drying and further autoclaving at } 121^{\circ} \mathrm{C} \text { during } 30 \mathrm{~min}\end{array}$ & Phorbol esters and antinutrients were still active & [59] \\
\hline 13 & Petroleum ether extraction & Phorbol esters reduced by $67.7 \%$ in kernels & [55] \\
\hline 14 & Double solvent extraction followed by moist heat treatment & Phorbol esters reduced by $70.8 \%$ in kernels & [55] \\
\hline 15 & $\begin{array}{l}\text { Double solvent extraction+wet extrusion, re-extraction with hexane } \\
\text { and moist heat treatment }\end{array}$ & Phorbol esters reduced by $87.7 \%$ in kernels & [55] \\
\hline 16 & Ethanol $(80 \%)$ or methanol $(92 \%)$ & $\begin{array}{l}\text { Saponins and phorbol esters reduced by } 95 \% \text { after } \\
\text { four extractions }\end{array}$ & {$[58]$} \\
\hline \multirow[t]{2}{*}{17} & Moist heating at $121^{\circ} \mathrm{C}$ for $20 \mathrm{~min}$ & $\begin{array}{l}\text { No effect on phorbol esters, Trypsin inhibitors total } \\
\text { inactivation }\end{array}$ & {$[58]$} \\
\hline & Radiation treatments & & \\
\hline 1 & Gamma irradiation of cake $(30 \mathrm{kGy})$ at the rate of $2.5 \mathrm{kGy} / \mathrm{hr}$ & Phorbol ester reduction by $75.8 \%$ & [50] \\
\hline 2 & UV irradiated ( 220 to $400 \mathrm{~nm}$ ) Jatropha oil at $25^{\circ} \mathrm{C}$ for $40 \mathrm{~min}$ & $100 \%$ reduction of phorbol esters & [70] \\
\hline 3 & $\begin{array}{l}\text { TPA (phorbol-12-myristate-13-acetate) degradation process by } \\
\text { microbubbles enhanced ozonolysis }\end{array}$ & $\begin{array}{l}12 \text { ppm of TPA in mixture with distilled water can } \\
\text { be fully decomposed within } 10 \text { min }\end{array}$ & [74] \\
\hline 4 & Ozonation of the moist seedcake & $\begin{array}{l}\text { Reduction of the phorbol esters } \\
\text { concentration by }>80 \%\end{array}$ & [75] \\
\hline
\end{tabular}




\section{Use of radiations}

Years of observations on various species for many generations led to conclude that the irradiated foods are safe and non-toxic to consume [67]. Irradiation has the advantages of very high performance and less secondary pollution and therefore can be considered as an additional processing method for removing both heat-stable and heat-labile anti-nutrients [67]. Irradiation techniques have been employed for the degradation and transformation of anti-nutritional compounds and several suspicious carcinogens $[68,69] . \gamma$ - Radiations have been tried by Gogoi et al. [50] to detoxify the seed cake and $75 \%$ reduction was achieved within $12 \mathrm{~h}$ of treatment. The combination of UV irradiation and chemical treatments has also experimented for the reduction of phorbol esters. Xiao et al. [70] irradiated Jatropha oil at $25{ }^{\circ} \mathrm{C}$ for $40 \mathrm{~min}$ and the wavelengths ranged from 220 to 400 $\mathrm{nm}$ which resulted in $100 \%$ reduction of the phorbol esters. Not much research is documented as far as radiation therapy for detoxifying the phorbol esters.

\section{Biological detoxification}

On the contrary, bio-detoxification does not involve the application of any chemicals or mixes and taking into consideration the safety and energy concerns; the biological methods are more advantageous than the others. But at the same time bio-detoxification may be inconvenient and time-consuming. Biodetoxification of Jatropha seed has been done using white rot fungi [76], Aspergillus niger, Penicillium chrysogenum, Rhizopus oligosporus, Rhizopus nigricans and Trichoderma longibrachitum [77] and many other microorganisms have been used to inactivate the toxins and antinutritional factors in Jatropha kernel meal (table 2).

Table 2: Various biological treatments for removal the of toxins in Jatropha press cake

\begin{tabular}{|c|c|c|c|}
\hline $\begin{array}{l}\text { S. } \\
\text { No. }\end{array}$ & Process/treatment & $\begin{array}{l}\text { Effects on phorbol esters and } \\
\text { other anti-nutritional factors }\end{array}$ & Reference \\
\hline 1. & $\begin{array}{l}\text { Fermentation in broth cultures by Trichoderma harzianum, T. harzianum, } \\
\text { Paecilomycessinensi, Cladosporium cladosporioides, Fusarium chlamydosporum, F. } \\
\text { chlamydosporum and F. chlamydosporum }\end{array}$ & $\begin{array}{l}\text { Phorbol esters are removed by } 88.9 \\
\%-99.7 \% \text { after } 30 \mathrm{~d} \text { of incubation. }\end{array}$ & [78] \\
\hline 2. & Solid state fermentation of Jatropha seed cake with white rot fungi for $20 \mathrm{~d}$ & Phorbol esters totally removed & [79] \\
\hline 3. & Submerged fermentation by bacillus strains & $\begin{array}{l}100 \% \text { phorbol esters degradation } \\
\text { achieved in } 7 \mathrm{~d} \text {. }\end{array}$ & [80] \\
\hline 4 & $\begin{array}{l}\text { Solid state fermentation of seed cake with Streptomyces filmicarius (YUCM 310038) in } \\
9 \mathrm{~d}\end{array}$ & $\begin{array}{l}\text { Phorbol esters are reduced by } 97 \% \\
\text { in seed cake. }\end{array}$ & [81] \\
\hline 5 & Solid state fermentation of seed cake with Cunninghamella echinulata CJS-90 in $12 \mathrm{~d}$. & $\begin{array}{l}\text { Degradation of phorbol esters to the } \\
\text { extent of } 75-100 \% \\
\text { Phytate degradation in the fermented } \\
\text { JSC was in the range of } 65-96 \% \text {. } \\
\text { Reduction of saponin was in the } \\
\text { range of } 55-99 \%\end{array}$ & [82] \\
\hline 6 & Solid state fermentation of Jatropha kernel cake with Absidiaspinosa, Mucorrouxii & $\begin{array}{l}\text { Tannin, Saponin and phytate } \\
\text { contents decreased }\end{array}$ & [83] \\
\hline 7 & $\begin{array}{l}\text { Jatropha curcas fermented by consortium of Aspergillus niger and Neurospora } \\
\text { sitophila ( } 3 \text { g inoculum and } 3 \mathrm{~h} \text { of fermentation time) }\end{array}$ & Phorbol esters reduced by $79.69 \%$ & [84] \\
\hline 8 & $\begin{array}{l}\text { Solid state fermentation of seed cake with white-rot fungi Bjerkanderaadusta or } \\
\text { Phlebiarufa }\end{array}$ & $\begin{array}{l}\text { Phorbol esters reduced by } 91-97 \% \text { in } \\
\text { seed cake }\end{array}$ & [76] \\
\hline 9 & $\begin{array}{l}\text { Solid state fermentation of seed cake with Pseudomonas aeruginosa PseA strain } \\
\text { within } 9 \mathrm{~d} \text { under } 30^{\circ} \mathrm{C}, \mathrm{pH}=7 \text { and } 65 \% \text { relative humidity }\end{array}$ & $\begin{array}{l}\text { Phorbol esters reduced to } \\
\text { undetectable level }\end{array}$ & [85] \\
\hline 10. & $\begin{array}{l}\text { Solid state fermentation of Jatropha curcas kernel cake with Aspergillus niger, } \\
\text { Penicillium sp., Trichoderma harzanium and Trichoderma longibrachiatum in } 10 \mathrm{~d} \text {. }\end{array}$ & $\begin{array}{l}\text { Tannin and phytate contents were } \\
\text { reduced }\end{array}$ & [86] \\
\hline 11. & Solid state fermentation of Jatropha seed cake with P. ostreatus for 45-days incubation & $99 \%$ degradation of phorbol esters & [87] \\
\hline 12. & Fermentation of Jatropha seed cake with P. ostreatus for $60 \mathrm{~d}$ & $\begin{array}{l}\text { Phorbol ester concentration was } \\
\text { reduced by } 99 \%\end{array}$ & [88] \\
\hline
\end{tabular}

We hypothesised that there are such microorganisms in nature which have the potential of degrading all kinds of the toxins of the kernel cake at the same time. We obtained such a strain in our lab by a high throughput strain isolation and screening approach from soil and detoxified $(100 \%)$ the kernel cake by an ecologically friendly submerged fermentation (SmF) by the newly isolated strain (unpublished data). A pilot scale detoxification was carried out using our strain Pseudomonas in submerged fermentation with a fresh batch of Jatropha seed cake for a period of $3,6,9$ and $12 \mathrm{~h}$. It was observed with an increase in incubation time there was a decrease in the amount of phorbol esters in the seed cake because of the release of esterolytic enzymes by the strain Pseudomonas. The esterolytic enzymes break the compound into phorbol, myristic acid and acetic acid. Since these compounds are non-toxic, the aim of detoxifying the seed cake was fulfilled. Complete degradation of phorbol esters from the seed cake takes $12 \mathrm{~h}$, which might be considered long for the industry. So, optimisation studies will be carried out to extract maximum phorbol esters faster and more efficiently. Many research groups across the globe are involved in parallel research to develop biotechnological strategies to overcome the challenges of phorbol esters toxicity.

After detoxification, Jatropha proteins can be extracted as they are present in high amounts and can be used as potential components for animal feed, while without detoxification Jatropha proteins are limited to technical applications. In a study conducted by Malviya et al. [89], the protein from the seed extract of Jatropha curcas was isolated by column chromatography which had a solubility of about $90 \%$ above $\mathrm{pH} 9$ and suggested it can be used as a good protein source in food applications, in improving dietary supplement products and protein energy product. Jatropha proteins were also extracted from the Jatropha seeds using the principle of isoelectric precipitation $[90,91]$. Sodium dodecyl sulphate polyacrylamide gel electrophoresis (SDS-PAGE), elemental analysis and Fourier transform infrared spectroscopy (FTIR) were used to analyse the obtained proteins. Liliana et al. [92] extracted Jatropha protein by alkaline extraction followed by isoelectric precipitation method by which they were able to obtain a protein isolate with $93.21 \%$ of proteins.

\section{CONCLUSION}

Detoxifying the seed cake with multifaceted toxic constituents is still a great challenge to the Jatropha industry. Several chemical and physical methods have failed to make headway to fully degrade phorbol esters from Jatropha curcas seed cake to convert it to animal feed. However, methanol and ethanol extractions have the potential to completely remove (not degrade) the phorbol esters from the kernel cake. But, handling or the disposal of the toxins raises an 
environmental and health concern. In addition, the use of an organic solvent is expensive and could have a residual effect on the animals and human beings consuming the feed. However, among three detoxification techniques, for environmental awareness with safety and energy concerns, the biological method would be more advantageous than the others.

\section{ACKNOWLEDGEMENT}

The first two authors acknowledge DTU and UGC for providing research fellowships.

\section{CONFLICT OF INTERESTS}

The authors declare that there is no conflict of interest.

\section{REFERENCES}

1. Makkar HPS, Becker K. Jatropha curcas, a promising crop for the generation of biodiesel and value-added coproducts. Eur J Lipid Sci Technol 2009;111:773-87.

2. Abou-Arab A, Abu-Salem FM. Nutritional quality of Jatropha curcas seeds and effect of some physical and chemical treatments on their anti-nutritional factors. Afr J Food Sci 2010;4:93-103.

3. Aregheore EM, Becker K, Makkar HPS. Detoxification of a toxic variety of Jatropha curcas using heat and chemical treatments, and preliminary nutritional evaluation with rats. S Pac J Nat Sci 2003;21:50-6.

4. Makkar HPS, Becker K. Removal and degradation of phorbol esters during pre-treatment and transesterification of Jatropha curcas oil. J Am Oil Chem Soc 2009;86:173-81.

5. Parawira W. Biodiesel production from Jatropha curcas: a review. Sci Res Essays 2010;5:1796-808.

6. Trabuccu A, Achten WMJ, Bowe C. Global mapping of Jatropha curcas yield based on the response of fitness to present and future climate. Glob Change Biol Bioenergy 2010;2:139-51.

7. Dehgan B, Webster GL. Morphology and infrageneric relationships of the genus Jatropha (Euphorbiaceae). The university of California Publications in Botany; 1979. p. 74.

8. Internet source-2. Available from: http://www. Jatrophabiodiesel.org/aboutJatrophaPlant.php?_divid=menu1. [Last accessed on 20 Aug 2016]

9. Gour VK. Production practices including post-harvest management of Jatropha curcas. In: Proceedings of the biodiesel conference toward energy independence-Focus of Jatropha; 2006. p. 223-351.

10. Internet source-1. Available from: http://www.Jatropha.pro/ PDF\%20bestanden/Cultivation\%20of\%20Jatropha\%20curcas\%2 0in\%20India.pdf. [Last accessed on 20 Aug 2016]

11. Estrin AN. Development of the Jatropha cultivation and biodiesel production: Case of Karnataka State, India, Imperical College, London, UK; 2009.

12. Inekwe UV, Lodey MO, Gauje B, Dakare AM, Nkeonye O, Bala S, et al. Comparative proximate composition of partially de-oiled Jatropha curcas seed from India, kaduna and edo. Adv Sci Eng 2012;4:151-4.

13. Achten WM J, Almeida J, Fobelets V, Bolle E, Mathijs E, Singh VP, et al. Life cycle assessment of Jatropha biodiesel as a transportation fuel in rural India. Appl Energy 2010;87:3652-60.

14. Gubitz GM, Mittelbach M, Trabi M. Exploitation of the tropical oil seed plant Jatropha curcas L. Bioresour Technol 1999;67:73-82.

15. Martınez Herrera J, Siddhuraju P, Francis G, Davila-Ortiz G, Becker K. Chemical composition, toxic/antimetabolic constituents, and effects of different treatments on their levels, in four provenances of Jatropha curcas L. from Mexico. Food Chem 2006;96:80-9.

16. Thenmozhi $\mathrm{K}$, Saradha $\mathrm{M}$, Manian S, Paulsamy S. In vitro antimicrobial potential of root extracts of the medicinal plant species, Emilia sonchifolia (linn.) dc. Asian J Pharm Clin Res 2013;6:149-51.

17. Richa T, Gaurav S, Nakuleshwar DJ, Ekta M. Indian medicinal plants as an effective antimicrobial agent. J Crit Rev 2016;3:69-71.

18. Kinsalin VA, Kumar PS, Duraipandiyan V, Ignacimuthu S, Dhabi NAA. Antimicrobial activity of methanol extracts of some traditional medicinal plants from Tamil Nadu, India. Asian J Pharm Clin Res 2014;7:36-40.
19. Swarnamoni D, Mukundam B, Shagufa A. Antibacterial activity of the ethanolic extract of leaves of citrus maxima (burm.) merr. on Escherichia coli and Pseudomonas aeruginosa. Asian J Pharm Clin Res 2013;6(Suppl 4):136-9.

20. Esimone CO, Nworu CS, Jackson CL. Cutaneous wound healing activity of an herbal ointment containing the leaf extract of Jatropha curcas L. (Euphorbiaceae). Int J Appl Res Nat Prod 2008;1:1-4.

21. Oskoueian E, Abdullah N, Saad WZ, Omar AR, Ahmad S, Kuan $\mathrm{WB}$, et al. Antioxidant, anti-inflammatory and anticancer activities of methanolic extracts from Jatropha curcas Linn. J Med Plants Res 2011;5:49-57.

22. Singh B, Bhat TK, Singh B. Potential therapeutic applications of some antinutritional plant secondary metabolites. J Agric Food Chem 2003;51:5579-97.

23. Prasad DMR, Izam A, Khan MR. Jatropha curcas: a plant of medical benefits. J Med Plants Res 2012;6:2691-9.

24. Thomas R, Sah NK, Sharma PB. Therapeutic biology of Jatropha curcas: a mini review. Curr Pharm Biotechnol 2008;9:315-24.

25. Henning K. Fuel production improves food production: the Jatropha project in Mali. In: Biofuels and Industrial products from Jatropha curcas. Gubitz GM, Mittelbach M, Trabi M. Eds. DBV Graz; 1997. p. 92-7.

26. Heller J. Physic Nut. Jatropha curcas L. Promoting the conservation and use of underutilised and neglected crops. International Plant Genetic Resources Institute, Rome; 1996.

27. Akinpelu DA, Aiyegoro OA, Okoh AI. The bioactive potentials of two medicinal plants commonly used as folklore remedies among some tribes in West Africa. Afr J Biotechnol 2009;8:1660-4.

28. Aiyelaagbe 00, Adeyeni BA, Fatunsin OF, Arimah BD. In vitro antimicrobial activity and phytochemical analysis of Jatropha curcas roots. Int J Pharmacol 2007;3:106-10.

29. Kalimuthu K, Vijayakumar S, Senthilkumar R. Antimicrobial activity of the biodiesel plant, Jatropha curcas. Int J Pharm Biol Sci 2010;1:1-5.

30. Ekundayo EO, Ekekwe JN. Antibacterial activity of leaves extracts of Jatropha curcas and Euphorbia heterophylla. Afr J Microbiol Res 2013;7:5097-100.

31. Arekemase MO, Kayode RMO, Ajiboye AE. Antimicrobial activity and phytochemical analysis of Jatropha curcas plant against some selected microorganisms. Int J Biol 2011;3:52-9.

32. Arun K, Anu B, Ruchika G. A comparative study of antibacterial activity of leaves and latex of Jatropha curcas L. Int J Pharm Phytochem Res 2012;4:190-4.

33. Leonard GOA, Betty E, Omolara MA, Aniekpeno IE, Obinna TE. Antimicrobial activity of extracts of Jatropha curcas and Calotropis procera leaves against pathogenic isolates from motorcycle helmets in Lagos metropolis Int J Curr Microbiol Appl Sci 2013;2:292-302.

34. Nwankwo JI, Nwankwo BN. A Preliminary comparative study on the antimicrobial properties of Cassia alata, Jatropha curcas. IOSR J Pharm Biol Sci 2014;9:37-40.

35. Rachana S, Tarun A, Rinki R, Neha A, Neha, Meghna R. Comparative analysis of the antibacterial activity of Jatropha curcas fruit parts. J Pharm Biomed Sci 2012;15:1-4.

36. Beni S, Amran L, Meta M, Firdaus. Antibacterial activity of leaves extracts of, linn against Enterobacter aerogenes. Int J Sci Technol Res 2014;3:129-31.

37. Thomas 00. Re-examination of the antimicrobial activities of Xylopiaaethiopica, Carica papaya, Ocimium gratissimum and Jatropha curcas. Fitoterapia 1989;60:147-61.

38. Egharevba HO, Kunle OF. Broad spectrum antimicrobial activity of extracts of Jatropha curcas. J Appl Pharm Sci 2013;3:83-7.

39. Rajesh SG, Rajendra BK, Anil UK, Deepmala RG, Panchal VH. In vitro antimicrobial activity of crude extracts of Jatropha species. Curr Bot 2012;3:9-15.

40. Deepmala AG. In vitro antibacterial activity of crude extracts of Jatropha species. Sci Res Rep 2013;3:159-63.

41. Akbar E, Yaakob Z, Kamarudin S, Ismail M. Characteristics and composition of Jatropha curcas oil seed from Malaysia and its potential as a biodiesel feedstock. Eur J Sci Res 2009;29:396-403. 
42. Makkar HPS, Kumar V, Becker K. Use of detoxified Jatropha kernel meal and protein isolate in diets of farm animals. In: Makkar HPS. Biofuel co-products as livestock feed opportunities and challenges, FAO; 2012. p. 351-78.

43. Goel G, Makkar HPS, Francis G, Becker K. Phorbol esters: structure, biological activity and toxicity in animals. Int J Toxicol 2007;26:279-88.

44. Adam, SEI. Toxic effects of Jatropha curcas in Mice. Toxicology 1974;2:67-76

45. Cai-Yan L, Devappa KR, Jian-Xin L, Jian-Min L, Makkar HPS, Becker K. Toxicity of Jatropha curcas phorbol esters in mice. Food Chem Toxicol 2010;48:620-5.

46. Devappa RK. Isolation, characterization and potential agropharmaceutical application of phorbol esters from Jatropha oil. $\mathrm{Ph}$. D. thesis, University of Hohenheim; 2012.

47. Beutler JA, Ada AB, McCloud TG, Cragg GM. Distribution of phorbol ester bioactivity in the Euphorbiaceae. Phytother Res 1989;3:188-92.

48. Haas W, Sterk H, Mittelbach M. Novel 12-deoxy-16hydroxyphorbol diesters isolated from the seed oil of Jatropha curcas. J Nat Prod 2002;65:1334-440.

49. Ahmed AW, Salimon J. Phorbol ester as toxic constituents of tropical Jatropha curcas seed oil. Eur J Sci Res 2009;31:429-36.

50. Gogoi R, Niyogi UK, Tyagi AK. Reduction of phorbol ester content in Jatropha cake using high energy gamma radiation. J Radiat Res Appl Sci 2014;7:305-9.

51. Wink M, Koschmieder C, Sauerwein M, Sporer F. Phorbol esters of $J$. curcas - biological activities and potential applications. In: Gübitz GM, Mittelbach M, Trabi M. Eds. Biofuels and Industrial products from Jatropha curcas. Dbv, Graz; 1997. p. 160-6.

52. Becker K, Makkar HPS. Effects of phorbol esters in carp (Cyprinuscarpio L). Vet Hum Toxicol 1998;40:82-6.

53. Makkar HPS, Becker K. Jatropha curcas toxicity: identification of toxic principle (s). In: Garland T, Barr AC. Eds. Toxic Plants and Other Natural Toxicants. CAB International, New York; 1997a. p. 554-8.

54. Makkar HPS, Becker K. Potential of Jatropha curcas seed meal as a protein supplement in livestock feed, constraints to its utilisation and possible strategies to overcome constraints. Developed from the Symposium-Jatropha, Managua, Nicaragua. Biofuel and Industrial Products from J. curcas; 1997b. p. 190-205.

55. Chivandi E, Mtimuni JP, Read JS, Makuza SM. Effect of processing method on phorbol ester concentration, total phenolics, trypsin inhibitor activity and the proximate composition of the Zimbabwean Jatropha curcas provenance: a potential livestock feed. Pak J Biol Sci 2004;7:1001-5.

56. Rakshit KD, Makkar HPS. Optimisation of conditions for the extraction of phorbol esters from Jatropha oil. Biomass Bioenergy 2010;34:1125-33

57. Sadubthummarak U, Parkpian P, Ruchirawat M, Kongchum M, Delaune RD. Potential treatments to reduce phorbol esters levels in Jatropha seed cake for improving the value added product. J Environ Sci Health Part B 2013;48:974-82.

58. Makkar HPS, Becker K, Sporer F, Wink M. Studies on nutritive potential and toxic constituents of different provenances of Jatropha curcas. J Agric Food Chem 1997;45:3152-7.

59. Chivandi E, Erlwanger KH, Makuza SM, Read JS, Mtimuni JP Effects of dietary Jatropha curcas meal on percent packed cell volume, serum glucose, cholesterol and triglyceride concentration and alpha-amylase activity of weaned fattening pigs. Res J Anim Vet Sci 2006;1:18-24.

60. Pighinelli ALMT, Ferrari RA, Machado MCNA, Park KJ. Study of Jatropha curcas L. cake detoxification. Energy, biomass and biol. Residues Int Conf Agric Eng Agric for a healthier Life, Valencia, Spain; 2012

61. Vittaya P, Rayakorn N. Comparison of detoxification methods on phorbol esters in deoiled Jatropha curcas meal for animal feeds. J Chem Chem Eng 2013; 7:533-8.

62. Severa G, Kumar G, Troung M, Young G, Michael JC. Ionic liquid co-solvent assisted extraction of phorbol esters from Jatropha biomass. Sep Purif Technol 2013;116:265-70.

63. Guedes RE, Cruza FA, Lima MC, Sant'Ana L, Castro RN, Mendes MF. Detoxification of Jatropha curcas seed cake using chemical treatment: analyses with a central composite rotatable design. Ind Crops Prod 2014;52:673-9.

64. Gaur S. Development and evaluation of an effective process for the recovery of oil and detoxification of meal from Jatropha curcas. MSc. Thesis, Missouri University of Science and Technology, USA; 2009.

65. Pereira CSS, Rocha RR, Pessoa FLP, Mendes MF. Phorbol esters extraction from Jatropha curcas seed cake using supercritical carbon dioxide, III Iberoamerican Conference on Supercritical Fluids Cartagena de Indias (Colombia); 2013.

66. Diwani GIE, Rafei SAE, Hawash SI. Ozone for phorbol esters removal from egyptian Jatropha oil seed cake. Adv Appl Sci Res 2011;2:221-32.

67. Chen SQ Jiang KX, Cao BS, Liu YQ Cai XF, Liu XL, et al. Distribution of irradiated foods in China. Food Control 2012;28:237-9.

68. Mir NA, Khan A, Muneer M, Vijayalakhsmi S. Photocatalytic degradation of a widely used insecticide thiamethoxam in an aqueous suspension of TiO2: Adsorption, kinetics, product analysis and toxicity assessment. Sci Total Environ 2013;458:388-98.

69. de Urzedo AP, Diniz M, Nascentes CC, Catharino RR, Eberlin MN, Augusti R. Photolytic degradation of the insecticide thiamethoxam in aqueous medium monitored by direct infusion electrospray ionisation mass spectrometry. J Mass Spectrom 2007;42:1319-25.

70. Xiao J, Mao X, Zhang H, Niu L. Detoxification of Jatropha curcas oil by ultraviolet irradiation combined with ethanol washing. Grasas Aceites 2015;66:e063.

71. Elangovan AV, Gowda NKS, Satyanarayan ML, Suganthi RU, Rao SBN. Jatropha (Jatropha curcas) seed cake as a feed ingredient in the rations of sheep. Anim Nutr Feed Technol 2013;13:57-67.

72. Kongmany S, Matsuura H, Furuta M, Okuda S, Imamura K, Maeda Y. Plasma application for detoxification of Jatropha phorbol Esters. J Phys: Conference Series 2006;441:501.

73. Rakshit KD, Bhagya S. Effect of processing methods on the removal of toxic and antinutritional constituents of Jatropha meal: a potential protein source. J Food Sci Technol 2007;3:88-95.

74. Kuvshinov D, Siswanto A, Zimmerman WB. Microbubbles enhanced synthetic phorbol ester degradation by ozonolysis. Int J Chem Mol Nucl Mat Metall Eng 2014;8:76-9.

75. Susan M, Brent S, Susan H, Paramjeet P, Alla A, Boubacar D, et al. Removal of phorbol ester from Jatropha seedcake using ozonation and solar irradiation. Ozone Sci Eng 2015;37:29-35.

76. de Barros CRM, Ferreira MML, Nunes FM, Bezerra RMF, Dias AA, Guedes CV, et al. The potential of white-rot fungi to degrade phorbol esters of Jatropha curcas L. seed cake. Eng Life Sci 2011;11:107-10.

77. Belewu MA, Sam R. Solid state fermentation of Jatropha curcas kernel cake: proximate composition and antinutritional components. J Yeast Fungal Res 2010;1:44-6.

78. Azhar N, Norhani A, Wan Z, Syahida A, Ehsan O, Faridah A, et al. Detoxification of toxic phorbol esters from Malaysian Jatropha curcas Linn. kernel by Trichoderma spp. and endophytic fungi. Int J Mol Sci 2014:15:2274-88.

79. Anjali B, Haresh K. Phorbol ester degradation in Jatropha seed cake using white rot fungi. Biotechnology 2014:4:447-50.

80. Chang CF, Weng JH, Lin KY, Liu LY, Yang SS. Phorbol esters degradation and enzyme production by Bacillus using Jatropha seed cake as substrate. Int I Environ Poll Rem 2014;2:30-6.

81. Xing HW, Lingcheng O, Liang LF, Shui Z, Ji-Dong LGL, Jiao L, et al. Detoxification of Jatropha curcas kernel cake by a novel Streptomyces fimicarius strain. J Hazard Mater 2013;260:238-46.

82. Somashekar D. Development of a biological method for degradation of toxins like phorbol esters and reduction of antinutrients in Jatropha curcas seed cake by solid state fermentation. J Anal Bioanal Technol 2013;4:5.

83. Sanusi GO, Belewu MA, Oduguwa BO, Enujiugha TF, Oluwole JYT, Okunlola AI. Changes in chemical composition of Jatropha curcas kernel cake after solid-state fermentation using some selected fungi. Global J Biol Agric Health Sci 2013;2:66-8.

84. Tuti K. Detoxification through fermentation by a consortium of Aspergillus niger and Neurospora sitophila towards the degree of forbol esther and nutrition value of Jatropha curcas L. for broiler's feed. J Asian Sci Res 2012;2:317-24.

85. Chetna J, Priyanka M, Khare SK. Degradation of phorbol esters by Pseudomonas aeruginosa PseA during solid-state fermentation 
of deoiled Jatropha curcasseed cake. Bioresour Technol 2011;102:4815-9.

86. Moshood AB, Olademeji A, Sherifat OI. Solid state fermentation of Jatropha curcas kernel cake with a cocktail of fungi. Int J Biosci 2011;1:12-9.

87. Kasuya MCM, da Luz JMR, Pereira LPS, da Silva JS, Montavani, Rodrigues MT. Biodetoxification of Jatropha seed cake and its use in animal feed. In: Fang Z. Biodiesel. Feedstocks, production and applications. Intech Croatia; 2012. p. 309-30.

88. Jose MRL, Mateus DN, Sirlaine AP, Denise PT, Maria C, Megum K. Biodetoxification of Jatropha curcas seed cake by Pleurotus ostreatus. Afr J Microbiol Res 2014;8:1148-56.

89. Malviya SN, Malakar R, Yadav M, Mishra A, Tiwari A. Estimation and characterization of protein present in seed extract of Jatropha curcas. Adv Res Pharm Biol 2011;1:35-44.
90. Hamarneh AI, Heeres HJ, Broekhuis AA, Picchioni. Extraction of Jatropha curcas proteins and application in polyketone-based wood adhesives. Int J Adhes Adhes 2010;30:615-25.

91. Kumar V, Makkar HPS, Becker K. Evaluations of the nutritional value of Jatropha curcas protein isolate in common carp (Cyprinuscarpio L.). J Anim Physiol Anim Nutr 2012;96:1030-43.

92. Liliana LL, Gloria DO, Cristian JM, Humberto HS. Sequentially integrated optimisation of the conditions to obtain a highprotein and low-antinutritional factors protein isolate from edible Jatropha curcas seed cake. ISRN Biotechnol 2013. http://dx.doi.org/10.5402/2013/197201

\section{How to cite this article}

- Shilpi Ahluwalia, Rajkumar Bidlan, Jai Gopal Sharma, Pushpendra Singh. Review on phorbol ester degradation of Jatropha seed cake for its use as animal feed. Int J Pharm Pharm Sci 2017;9(1):7-13. 